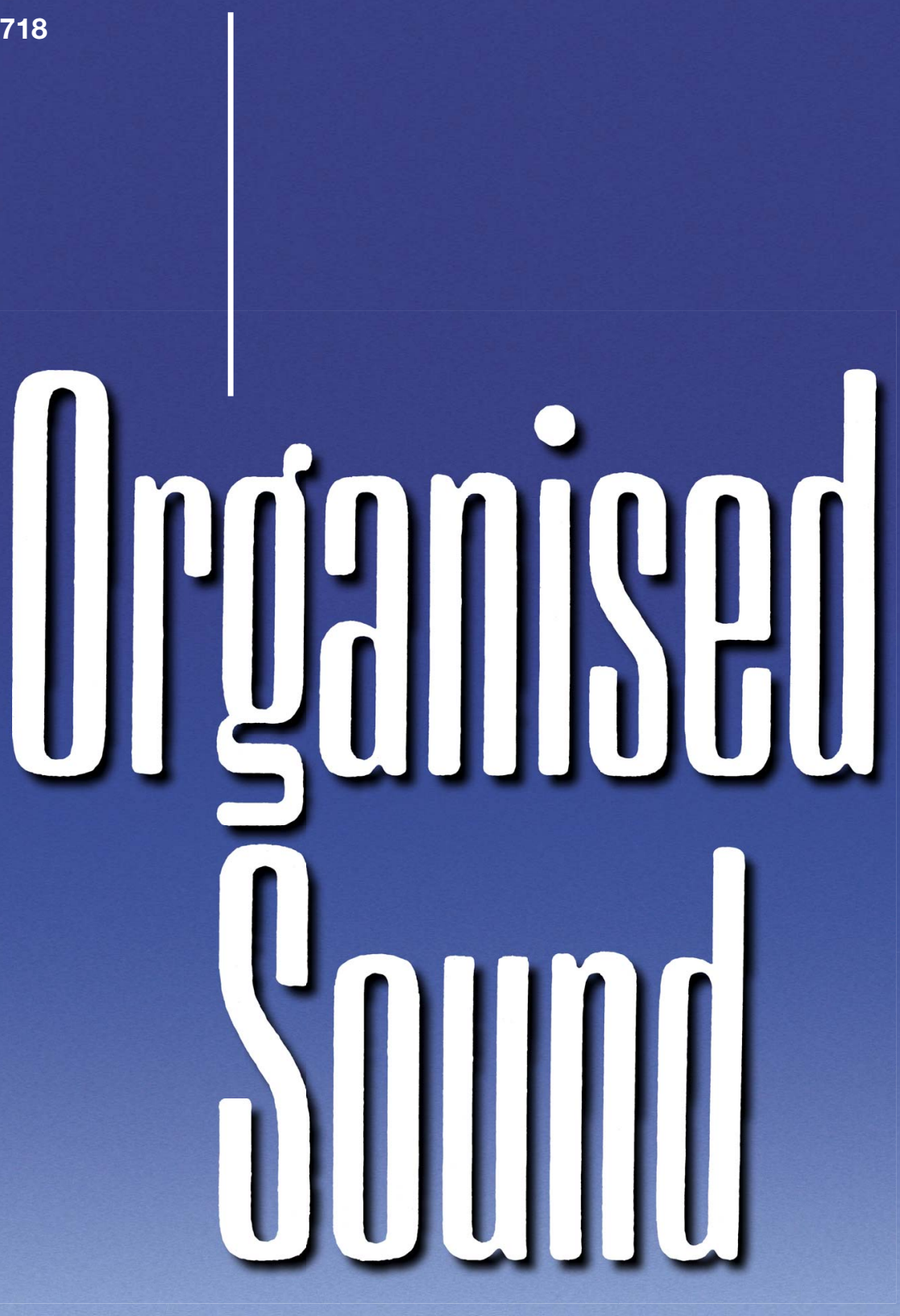

Volume 20 Issue 1

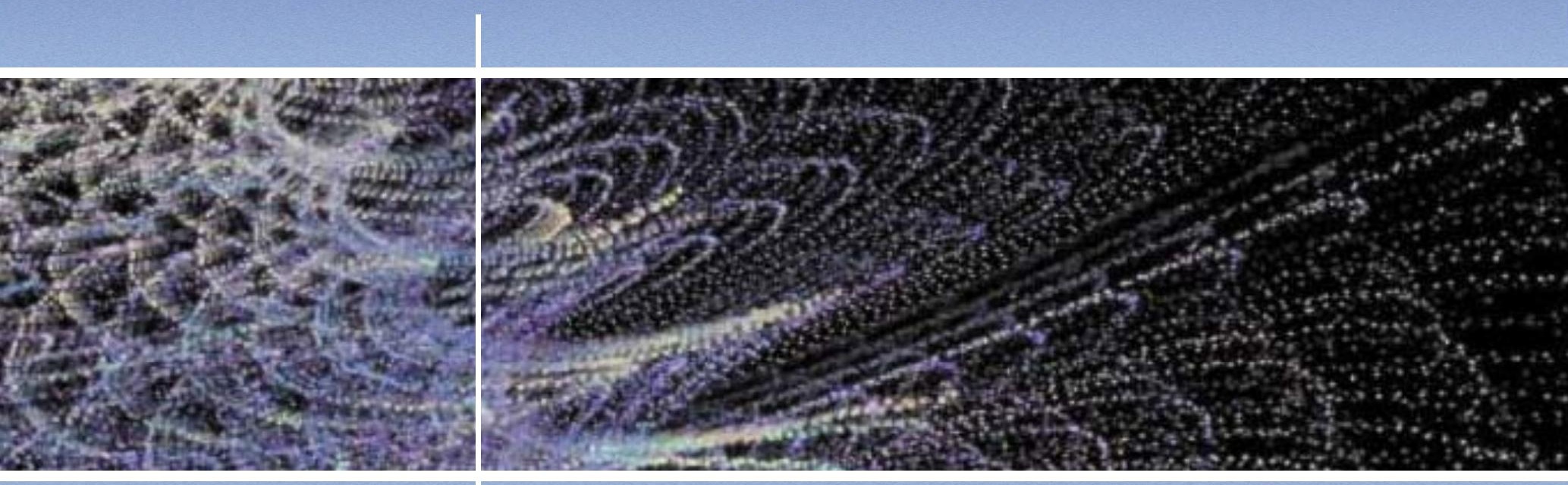

Special issue: Organised Sound Celebrates 20 Years 


\section{ORGANISED SOUND}

\section{EDITOR}

Leigh Landy

De Montfort University, Leicester

ASSOCIATE EDITORS

Ross Kirk

University of York

REGIONAL EDITORS

Ricardo Dal Farra (Latin and South America)

Concordia University Montreal

Jøran Rudi (Europe)

NOTAM, Norway

Margaret Schedel (North America)

Stony Brook University, New York

Barry Truax (North America)

Simon Fraser University

EDITORIAL BOARD

Marc Battier

Université de Paris IV-Sorbonne, Paris

Manuella Blackburn

Liverpool Hope University

Joel Chadabe

Intelligent Arts, New York

Alessandro Cipriani

Scuola di Musica Elettronica

Conservatorio di Musica Frosinone

Simon Emmerson

De Montfort University, Leicester

Kenneth Fields

Central Conservatory of Music, Beijing

Rajmil Fischman

University of Keele

Eduardo Miranda

University of Plymouth

\section{SUBSCRIPTIONS}

Organised Sound (ISSN 1355-7718, Electronic ISSN 1469-8153) is published three times a year in April, August and December. Three parts form a volume. An annual CD accompanies each volume in the last issue, and is free of charge to subscribers. The subscription price (excluding VAT and sales tax) of volume 20 (2015) (which includes postage) is $£ 229$ net (US\$409) for institutions print and electronic, institutions electronic only is $£ 196 / \$ 351$; and $£ 50$ net (US\$77) for individuals and $£ 30$ net (US\$44) for students ordering direct from the publisher and certifying that the journal is for their personal use. Single parts are $£ 84$ (US\$150) plus postage. US\$ rates are payable by subscribers in the USA, Canada and Mexico.

COPYING

This journal is registered with the Copyright Clearance Center, 27 Congress St., Salem, MA 01970, USA. Organisations in the USA who are also registered with C.C.C. may therefore copy material (beyond the limits permitted by sections 107 and 108 of U.S. Copyright law) subject to payment to C.C.C. of the per-copy fee of \$16.00. This consent does not extend to multiple copying for promotional or commercial purposes. Code 1355-7718/2015.

ISI Tear Sheet Service, 3501 Market Street, Philadelphia, PA 19104 , USA, is authorised to supply single copies of separate articles for private use only.

Organisations authorised by the Copyright Licensing Agency may also copy material subject to the usual conditions.

(C) Cambridge University Press 2015

Orders, which must be accompanied by payment, may be sent to a bookseller, subscription agent or direct to the publisher: Cambridge University Press, University Printing House,
Richard Orton ${ }^{\dagger}$

University of York

Ian Whalley (Australasia)

University of Waikato

David Worrall (Australasia)

Fraunhofer-Institut für Integrierte Schaltungen IIS, Germany

Lonce Wyse (Asia)

National University of Singapore

Rosemary Mountain

Concordia University, Montreal

Tony Myatt

University of Surrey

Katharine Norman

De Montfort University, Leicester

Garth Paine

Arizona State University, USA

Jean-Claude Risset

CNRS, Marseille

Mary Simoni

Rensselaer Polytechnic Institute

Martin Supper

Universität der Künste, Berlin

Daniel Teruggi

Institut National Audiovisuel,

Groupe de Recherches Musicales, Paris

Shaftesbury Road, Cambridge CB2 8BS, UK; or in the USA,

Canada and Mexico: Cambridge University Press, 100 Brook Hill Drive, West Nyack, NY 10994-2133, USA. EU subscribers who are not registered for VAT should add VAT at their country's rate. VAT registered subscribers should provide their VAT registration number. Japanese prices for institutions are available from Kinokuniya Company Ltd, PO Box 55, Tokyo 156, Japan. Prices include delivery by air. For all other use, permission should be sought from Cambridge or from the American Branch of Cambridge University Press.

POSTMASTER: send address changes to 100 Brook Hill Drive, West Nyack, NY 10994-2133

INTERNET ACCESS

Organised Sound is included in the CJO service at journals.cambridge.org

Information on Organised Sound and all other Cambridge journals can be accessed via http://www.cambridge.org/

Cambridge University Press

University Printing House, Shaftesbury Road, Cambridge CB2

8BS, UK, 32 Avenue of the Americas, New York, NY 10013-2473,

USA10 Stamford Road, Oakleigh, Melbourne 3166, Australia

This journal issue has been printed on FSC-certified paper and cover board. FSC is an independent, non-governmental, not-for-profit organization established to promote the responsible management of the world's forests. Please see www.fsc.org for information. 